\title{
Histological evaluation of a biomimetic material in bone regeneration after one year from graft
}

\author{
Michele M. Figliuzzi, DDS, PhD' \\ Rossella De Fazio, DDS ${ }^{1}$ \\ Rosamaria Tiano, DDS ${ }^{1}$ \\ Serena De Franceschi, DDS ${ }^{1}$ \\ Delfina Pacifico, DDS ${ }^{1}$ \\ Francesco Mangano, DDS 2 \\ Leonzio Fortunato, MD, PhD1 \\ 1 Department of Periodontics and Oral Sciences, \\ Magna Graecia University, Catanzaro, Italy \\ 2 Department of Biomaterials, Insubria University, \\ Varese, Italy
}

Corresponding author:

Michele M. Figliuzzi

Department of Periodontics and Oral Sciences, Magna Graecia University, Catanzaro

Via Tommaso Campanella 115

88100 Catanzaro, Italy

E-mail:raass@hotmail.it

\section{Summary}

Aim. The use of substitute materials is one of the solutions used in periodontology for the reconstruction of intrabony defects. Advances in scientific research gave rise to a new generation of biomaterials of synthetic origin stoichiometrically unstable and therefore really absorbable.

Our research is directed precisely towards a biomaterial synthesis, Engipore ${ }^{\circledR}$ (Finceramica, Faenza, Italy) which is a bone substitute of the latest hydroxyapatite-based generation, that possesses chemical and morphological properties similar to those of natural bone in the treatment of infrabony periodontal defects. Aim of this study was to evaluate the efficacy of Engipore ${ }^{\circledR}$ in the treatment of intrabony periodontal defects.

Methods. The study was conducted on 100 parodontopatics patients, which had gingival pockets of at least infrabonies $8 / 10 \mathrm{~mm}$. The histological evaluation was performed with samples after one year from the graft.

Results. The histological samples collected after one year showed an abundant new bone formation, with mature lamellar bone tissue surrounding the residual particles of Engipore ${ }^{\circledR}$ that appear completely osteointegrated. The surrounding connective tissue shows no signs of inflammation. Conclusions. The results obtained in our research demonstrated that, after a proper selection of patients and lesions, and applying an adequate surgical technique, this type of biomaterial in the treatment of periodontal defects acts in an optimal manner as a filler inducing the formation of new bone as evidenced by histological examinations.

Key words: biomimetic material, bone regeneration, periosteum, intrabony defects.

\section{Introduction}

Advances in scientific research gave rise to a new generation of biomaterials of synthetic origin stoichiometrically unstable and therefore really absorbable (1). In recent years, studies in tissue regeneration in periodontology had a significant development of synthetic materials, starting from hydroxyapatite. In particular, materials able to mimic the functions of the bone have been studied, and then trigger the mechanisms of their guided bone regeneration (1-3). However, in the literature, studies of hydroxyapatite-based biomaterials reported conflicting data. Some authors have shown that the hydroxyapatite implanted into the bone induces the formation of new bone, which adheres chemically to the surface of the biomaterial without the interposition of fibrous tissue (4-8).

Other authors have shown that hydroxyapatite acts well as a filler, inert, but would always surrounded by fibrous tissue with no evidence of osteogenesis (9-12). By literature, a conflicting point was the "Geometry of Surface" (osteoinductive geometric configuration) of the biomaterial used. As demonstrated by the studies of $\mathrm{Ri}$ pamonti et al. (13), the geometry of the surface is critical for the shape, locomotion and cell differentiation. In particular, the porosity and crystallinity of a biomaterial confer a proper reabsorbability and differentiation (14).

Our research is directed precisely towards a biomaterial synthesis, the Engipore $\AA$, which is a bone substitute of the latest generation hydroxyapatite-based that possesses chemical and morphological properties very similar to those of natural bone. This type of structure and its morphological and microstructural characteristic allows this material, just applied in situ, to absorb the full thickness bioactive proteins and growth factors present in the clot and releasing gradually, generating a rapid vascularization and making more effective osteogenesis (15-17).

It has high osteoconductive properties and kinetics of osseointegration of $9-18$ months $(2,3,18)$. It has excellent adaptability and machinability and volumetric rendering, making it ideal for many applications. They 
include: sinus lifts, periodontal defects and peri-implant dehiscence $(19,20)$. Depending on the size of the defect, it can be taken advantage by the amount of material required limiting waste, as the product is available in different packaging: in flakes from $0.5-1$ $\mathrm{mm}$ in diameter, $0.5 \mathrm{~g}$ and $\mathrm{g} 2 \times 0.5$ easily shaped into blocks of $10 \times 10 \times 10 \mathrm{~mm}$ and from $10 \times 5 \times 5 \mathrm{~mm}$.

The aim of this work was to evaluate the efficacy of Engipore ${ }^{\circledR}$ in the surgical treatment of infrabony periodontal defects.

\section{Materials and methods}

This study was conducted on 100 patients (40 male and 60 female) affected by periodontal disease which presented at least one infrabony defect.

Defects presented the following characteristics: pure 2- or 3-wall defects (radiographic intrabony component $>4 \mathrm{~mm}$ ), probing pocket depth (PPD) $>6 \mathrm{~mm}$, defect angle $>30^{\circ}$, mobility of the tooth less than grade 1-2.

Patients were enrolled in a Department of Periodontics and Oral Sciences, Magna Graecia University, Catanzaro, Italy and was approved by the Ethical Committee (n.997 del 17/09/2010).

The present study was performed following the principles outlined of the Declaration of Helsinki on experimentation involving human subjects. All enrolled patients signed and informed consent form after receiving through oral and written information about the procedures and treatment plan.

Inclusion criterium was:

Age $>18$ years

Exclusion criteria were:

Scarce oral hygiene;

Smoking;

Systemic disease or conditions that could influence the outcome of therapy and/or contraindicating surgery;

Previous periodontal surgery;

Chronic NSAIDs assumption;

Allergy to the used materials;

Drugs use as nifepidine, steroids, allantoin, estrogens, cyclosporine, bisphosphonates;

Pregnancy.

Selected patients underwent a non-surgical periodontal treatment (i.e., full-mouth scaling and root planning). After three months, patients were re-evaluated and the need of periodontal surgery was confirmed.

\section{Surgical Procedure}

Patients were given an antibiotic therapy (Amoxicillin and Clavulanic Acid $1 \mathrm{~g}, 2$ times a day for 6 days, starting the day before the surgery) and a local antiseptic therapy with Chlorhexidine $0.2 \%$ rinses for 10 days. Before surgery, a preliminary X-ray was taken with the parallel cone technique (Fig. 1). After local anesthesia (Mepivacain plus Adrenalin 1:100.000, Pierrel Italia), according to Cortellini et al. (1999), an intra-sulcular incision with a papilla preservation technique was made by means of a lancet (Beaver 64, Becton, Dickinson \& Co, USA) between the mesial tooth and the distal one. Flap was raised at a split thickness. Granulation tissue was removed with ultrasonic tools and curettes (Fig. 2).

Once the defect depth was measured, root conditioning with tetracycline $0.5 \%$ was performed. In addition, a biomaterial was adapted Engipore ${ }^{\circledR}$ (Fig. 3). No membrane was used and, after filling the defect, the flap was coronally positioned and closed by means of

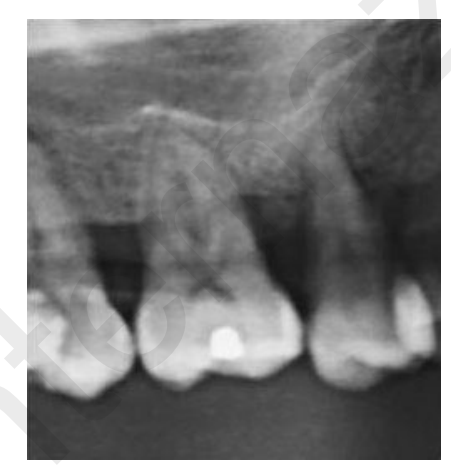

Figure 1. A preliminary $\mathrm{X}$-ray was taken with the parallel cone technique.

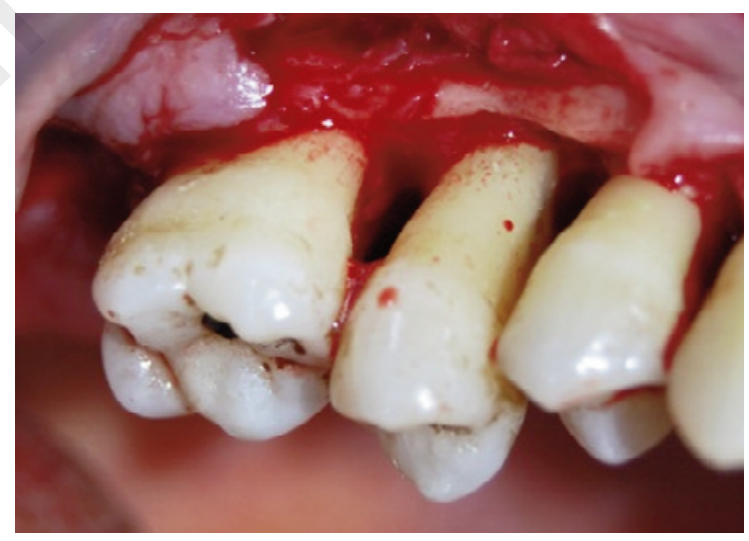

Figure 2. Vision of the bone defect after preparation of the flap.

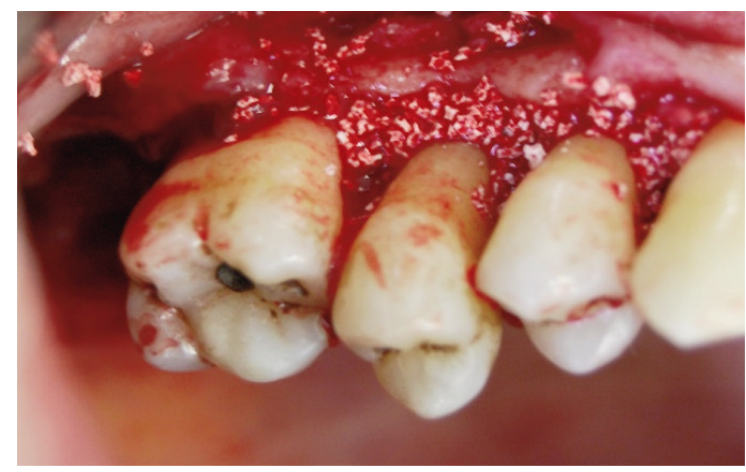

Figure 3. Defect filled with the biomaterial. 
mattresses sutures (Poliglycolic Acid, Distrex Spa Italia). In all cases a periodontal dressing was positioned. After 10 days, periodontal dressing and sutures were removed and patients were visited to evaluate healing (Fig. 4).

One year after grafting, a bone core was taken with a diameter of $2 \mathrm{~mm}$ at the graft site, under local anesthesia (Fig. 5). The tissue samples were then sent at a Department of Pathology performing histological analysis. The histological material maintained under $4 \%$ formalin. Than it was subjected to cuts of thickness $4-8 \mathrm{~mm}$ by microtome. Each section was colored by toluidine blue.

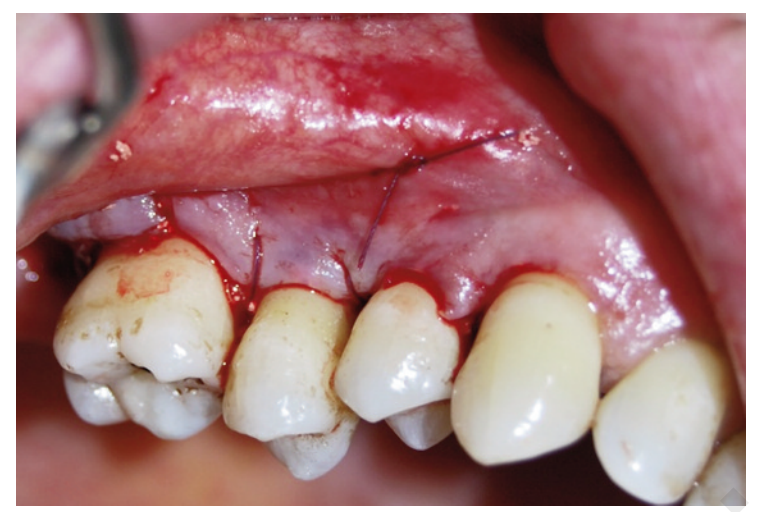

Figure 4. Suture.

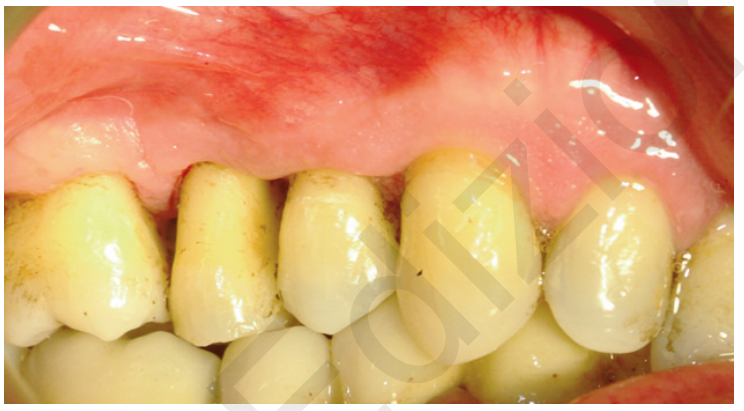

Figure 5. Healing of the soft tissues at 6 months.

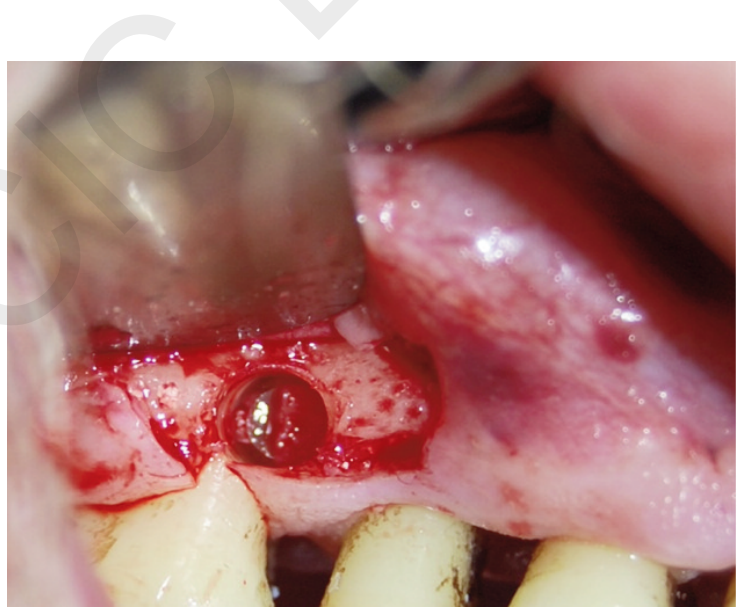

Figure 6. Vision Clinic of bone core performed at 6 months.

\section{Results}

Histological samples, one year after the graft (Figs. 610 ), showed abundant bone formation, with mature lamellar bone tissue surrounding the residual particles of Engipore ${ }^{\circledR}$ that appear completely osteointegrated. The surrounding connective tissue shows no signs of inflammation.

\section{Discussion}

In the present study, we wanted to evaluate the ability of integration of a biomimetic material of last generation, containing hydroxyapatite (21).

The hydroxyapatite used in this search has morphological and chemical properties very similar to those of natural bone. In fact, it has a porosity that reaches $90 \%$ of its volume in macropores with a range of 200 $500 \mu \mathrm{m}$ and pores of interconnection in the range of 80-200 microns. Thanks to its porosity, Engipore adsorb physiologic fluids so that cytokines and growth factors permeate in full thickness the material allowing bone forming cells to colonize and differentiate inside.

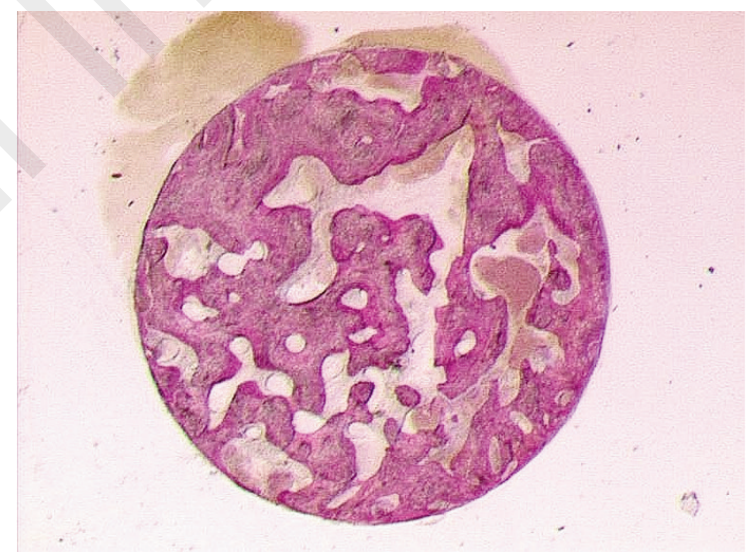

Figure 7. Bone core.

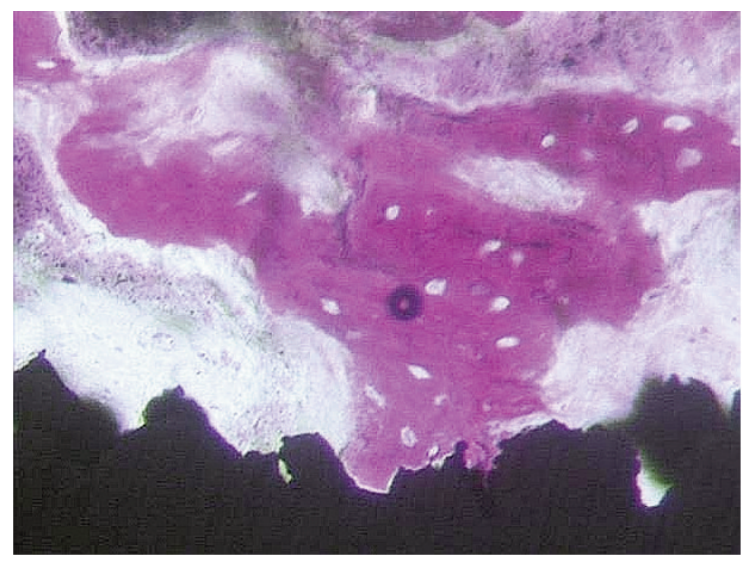

Figure 8. Presence of newly formed bone which surrounds some Engipore particles. 


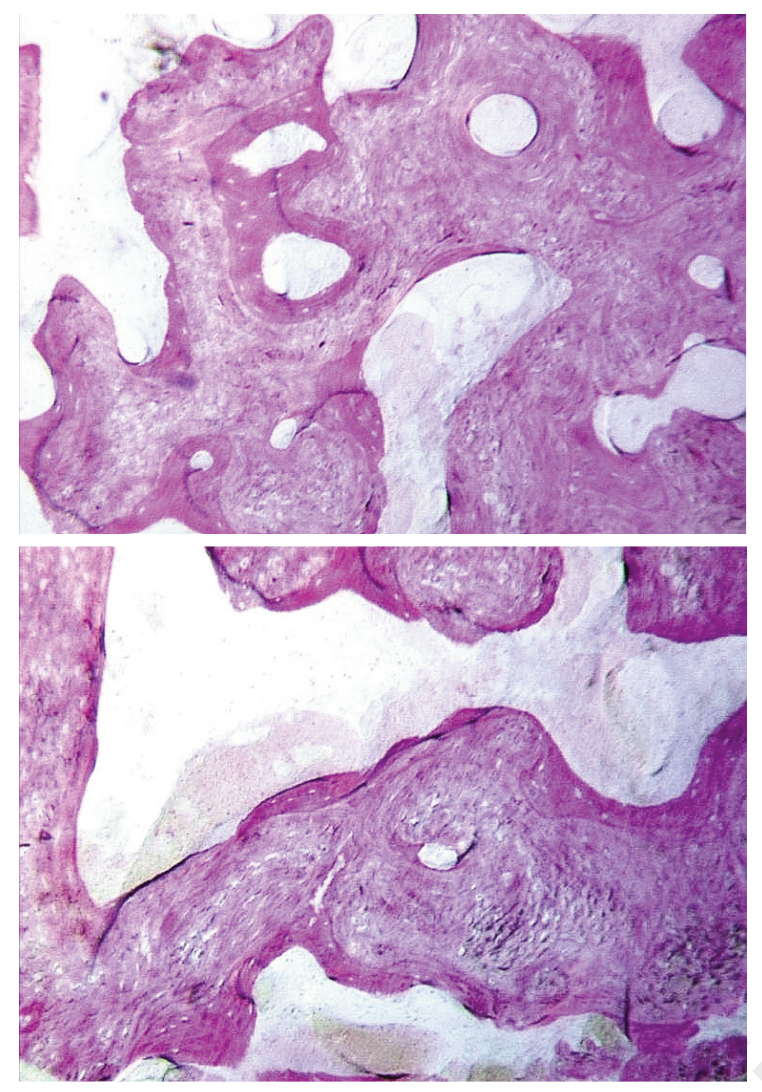

Figures 9-10. Not necrosis or inflammatory reaction, the graft material was almost completely reabsorbed and were obvious signs of osteogenesis.

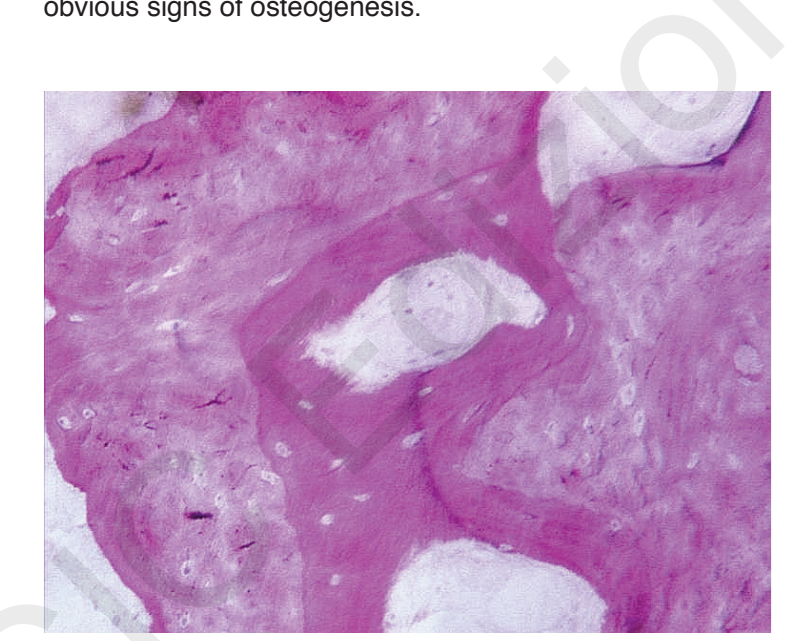

Figure 11. Engipore's particle with newly formed bone and osteocitaries gaps.

Engipore causes a significant induction of osteoblast transcriptional factors like SP7 and RUNX2 and of the bone-related gene osteocalcin (BGLAP) (22).

Furthermore, the $\mathrm{Ca} / \mathrm{P}$ ratio is practically similar to that present in the human bone. All this allows the material to have a similar surface geometry of human bone. This type of structure and the morphological microstructural characteristics, as pointed out by Ri- pamonti (13), allow this material, just applied in situ, to absorb the full thickness bioactive proteins and growth factors present in the clot and releasing gradually, generating a rapid vascularization and making more effective osteogenesis $(15,23,24)$. It has high osteoconductive properties and kinetics of osteointegration of 9-18 months (25-27).

In addition to the material used, we want to emphasize the importance that the surgical technique has in these types of interventions, which must be minimally invasive. The surgery was performed using the partial thickness flap.

This ensured adequate spraying of the surgical site throughout the duration of the treaty and allowed the suture anchor with subperiosteal guaranteeing the absolute stillness of the flap, a key condition to get a good recovery. Finally, it extolled the reparative and regenerative properties of bone tissue and periosteum, a locus of totipotent stem cells $(26,27)$.

Also the selection of the defects could be decisive in exalting the regenerative capacity of sites: those with 3 remaining walls are healed better than the sites where the residual walls were 2 (28). The histologies performed have shown bone formation around the particles of inert biomaterial.

\section{Conclusions}

Histological observations testify the excellent biocompatibility and good osseointegration properties of the biomaterial used in connection with the newly formed bone. The intimate relationship between the particles of the alloplastic material and the newly formed bone, in its various stages of formation and mineralization, allows to assert the ability of the osteoconductive material, that provide the scaffold for osteogenic reconstructive process.

\section{References}

1. Cortellini P, Tonetti M. Clinical performance of a regenerative strategy for intrabony defects. Scientific evidence and clinical experience. J Periodontol. 2005 Mar;76(3):341-50.

2. Needleman I, Tucker R, Giedrys-Leeper E, Worthington H. A systematic review of guided tissue regeneration for periodontal infrabony defects. J Periodontal Res. 2002;37:380-388.

3. Murphy KG, Gunsolley JC. Guided tissue regeneration for the treatment of periodontal intrabony and furcation defects. A systematic review. Ann Periodontol. 2003;8:266-302.

4. Scabbia A, Tampieri A, Trombelli L. I materiali bioceramici osteoconduttivi e il loro ruolo come sostituti dell'osso. Implantologia Orale. 2003; 4:9-25.

5. Ripamonti $\mathrm{U}$. The morphogenesis of bone in replicas of porous hydroxyapatite obtained from conversion of calcium carbonate exoskeletons of coral. J Bone Joint Surg Am. 1991;73:692-703.

6. Zhang XD. A study of porous block HA ceramics and its osteogenesis. In: Ravaglioli AA, Krajewski A, eds. Bioceramics and the Human Body. Amsterdam: Elsevier. 1991:408-415.

7. Yuan H, Li Y, Yang Z, Feng J, Zhang XD. An investigation on the osteoinduction of synthetic porous phase-pure hy- 
droxyapatite ceramics. Biomed Eng Appl Basis Com. 1997;9:274-278.

8. Okumura M, Ohgushi H, Dohi Y, et al. Osteoblastic phenotype expression on the surface of HA ceramics. J Biomed Mater Res. 1997;37:122-129.

9. lattelli A, Mangano C, Krajewski A, et al. Correlation between clinico-histological results and the hydroxyapatite phosphate ratio of implanted ceramic granules. In Andersson $\mathrm{OH}$, YliUrpo A (Eds.) Bioceramics, Vol.7 (Proceedings of the 7 th International Symposium on ceramics in medicine, Turku, Finland, July 1994):177-182.

10. DaculsI G, Legeros RZ, Nery E, et al. Transformation of biphasic calcium phosphate ceramics in vivo: ultrastructural and physicochemical characteristics. J Biomed Mater Res. 1989;23:883-894.

11. Nery EB, Legeros RZ, Lynch KL, Lee K. Tissue response to biphasic calcium phosphate ceramic with different ratios of HA/B-TCP in periodontal osseous defects. J Periodontal. 1992;63:729-735.

12. Di Domizio P, Scarano A, Piattelli M, et al. Healing of bone defects treated with hydroxyapatite particles. 76 th General Session and Exhibition of International Association for Dental Research (I.A.D.R.), Vancouver March 10-13, 1999.

13. Ripamonti U, Richter PW, Nilen RWN, Renton L. Induction of bone formation by smart biphasic hydroxyapatite tricalcium phosphate biomimetic matrices. Journal of Cellular and Molecular Medicine. 2008;12(6B):2609-2622.

14. Trisi $P, R a o W$. The bone growing Chamber: a new model to investigate spontaneous and guided bone regeneration of artificial defects in human jawbone. Int J Periodor Rest Dent. 1998;18:151-159.

15. Crespi R, Capparè P, Gherlone E. Magnesium-Enriched Hydroxyapatite Compared to Calcium Sulfate in the Healing of Human Extraction Sockets: Radiographic and Histomorphometric Evaluation at 3 Months. Journal of Periodontology. February 2009, Vol.80,No. 2: 210-218.

16. Neiva RF, Tsao YP, Eber R, Shotwell J, Billy E,Wang HL. Effects of a putty-formhydroxyapatite matrix combined with the synthetic cell-binding peptide P-15 on alveolar ridge preservation. J Periodontol. 2008;79:291-299.

17. Lechleitner $T$, Klauser F, Seppi $T$, Lechner J, Jennings $P$, Perco $P$, et al. The surface properties of nanocrystalline diamond and nanoparticulate diamond powder and their suitability as cell growth support surfaces. Biomaterials. 2008 Nov;29(32):4275-4284.

18. Jones EA, Kinsey SE, English A, Jones RA, Straszynski L, Meredith DM, et al. Isolation and characterization of bone marrow multipotential mesenchymal progenitor cells. Arthritis Rheum. 2002 Dec;46(12):3349-3360.

19. Scarano A, Degidi M, lezzi G, Pecora G, Piattelli A, Orsini G, Caputi S, Perrotti V, Mangano C. Maxillary sinus augmentation with different biomaterials. A comparative histologic and histomorphometric study in man. Implant Dent. 2006;15:197-207.

20. Aspiello S, Rasicci P, Piemontese M. Potenziale rigenerativo di gel piastrinico e bioceramica. Dental Cadmos. 2007.

21. Bartold M, Shi S, Gronthos S. Stem cells and Periodontal regeneration. Periodontology. 2000, Vol. 40, 2006;164-172.

22. Sollazzo V, Palmieri A, Girardi A, Farinella F, Carinci F. Engipore acts on human bone marrow stem cells. Saudi Dent J. 22, 161-6.

23. Neiva RF, Tsao YP, Eber R, Shotwell J, Billy E,Wang HL. Effects of a putty-formhydroxyapatite matrix combined with the synthetic cell-binding peptide P-15 on alveolar ridge preservation. J Periodontol. 2008;79:291-299.

24. Lechleitner $T$, Klauser F, Seppi T, Lechner J, Jennings $P$, Perco $P$, et al. The surface properties of nanocrystalline diamond and nanoparticulate diamond powder and their suitability as cell growth support surfaces. Biomaterials. 2008 Nov;29(32):4275-4284.

25. Jones EA, Kinsey SE, English A, Jones RA, Straszynski L, Meredith DM, et al. Isolation and characterization of bone marrow multipotential mesenchymal progenitor cells. Arthritis Rheum. 2002 Dec;46(12):3349-3360.

26. Cortellini P, Tonetti M. Microsurgical Approach to Periodontal Regeneration. Initial Evaluation in a Case Cohort Journal of Periodontology. Apr 2001, Vol. 72, No. 4:559-569.

27. Fickl S, Kebschull M, Schupbach $\mathrm{P}$, Zuhr O, Schlagenhauf $\mathrm{U}$, Hürzeler MB. Bone loss after full-thickness and partialthickness flap elevation. J Clin Periodontol. 2011 Feb;38(2):157-62.

28. Cortellini $\mathrm{P}$, Tonetti MS. Clinical and radiographic outcomes of the modified minimally invasive surgical technique with and without regenerative materials: a randomized-controlled trial in intra-bony defects. J Clin Periodontol. 2011 Apr;38(4):365-73. 